\title{
Capsule-Targeting Depolymerase, Derived from Klebsiella KP36 Phage, as a Tool for the Development of Anti-Virulent Strategy
}

\author{
Grażyna Majkowska-Skrobek ${ }^{1, *}$, Agnieszka Łątka ${ }^{1}$, Rita Berisio ${ }^{2}$, Barbara Maciejewska ${ }^{1}$, \\ Flavia Squeglia ${ }^{2}$, Maria Romano ${ }^{2}$, Rob Lavigne ${ }^{3}$, Carsten Struve ${ }^{4,5}$ and Zuzanna Drulis-Kawa ${ }^{1}$ \\ 1 Institute of Genetics and Microbiology, University of Wroclaw, Przybyszewskiego 63/77, \\ 51-148 Wroclaw, Poland; agnieszkalatka1989@gmail.com (A.Ł.); barbara-boczkowska@wp.pl (B.M.); \\ zuzanna.drulis-kawa@uwr.edu.pl (Z.D.-K.) \\ 2 Institute of Biostructures and Bioimaging, National Research Council, Via Mezzocannone 16, I-80134 Naples, \\ Italy; rita.berisio@unina.it (R.B.); squegliaflavia@gmail.com (F.S.); romanom87@hotmail.it (M.R.) \\ 3 Laboratory of Gene Technology, KU Leuven, Kasteelpark Arenberg 21, box 2462, B-3001 Leuven, Belgium; \\ rob.lavigne@kuleuven.be \\ 4 Department of Microbiology and Infection Control, Statens Serum Institut, Artillerivej 5, \\ DK-2300S Copenhagen, Denmark; CAS@ssi.dk \\ 5 World Health Organization Collaborating Centre for Reference and Research on Escherichia and Klebsiella, \\ Statens Serum Institut, Artillerivej 5, DK-2300S Copenhagen, Denmark \\ * Correspondence: grazyna.majkowska-skrobek@uwr.edu.pl; Tel.: +48-71-3756-296
}

Academic Editors: Tessa E.F. Quax, Matthias G. Fischer and Laurent Debarbieux Received: 22 September 2016; Accepted: 23 November 2016; Published: 1 December 2016

\begin{abstract}
The rise of antibiotic-resistant Klebsiella pneumoniae, a leading nosocomial pathogen, prompts the need for alternative therapies. We have identified and characterized a novel depolymerase enzyme encoded by Klebsiella phage KP36 (depoKP36), from the Siphoviridae family. To gain insights into the catalytic and structural features of depoKP36, we have recombinantly produced this protein of $93.4 \mathrm{kDa}$ and showed that it is able to hydrolyze a crude exopolysaccharide of a K. pneumoniae host. Using in vitro and in vivo assays, we found that depoKP36 was also effective against a native capsule of clinical K. pneumoniae strains, representing the K63 type, and significantly inhibited Klebsiella-induced mortality of Galleria mellonella larvae in a time-dependent manner. DepoKP36 did not affect the antibiotic susceptibility of Klebsiella strains. The activity of this enzyme was retained in a broad range of $\mathrm{pH}$ values (4.0-7.0) and temperatures (up to $45^{\circ} \mathrm{C}$ ). Consistently, the circular dichroism (CD) spectroscopy revealed a highly stability with melting transition temperature $(\mathrm{T} m)=65^{\circ} \mathrm{C}$. In contrast to other phage tailspike proteins, this enzyme was susceptible to sodium dodecyl sulfate (SDS) denaturation and proteolytic cleavage. The structural studies in solution showed a trimeric arrangement with a high $\beta$-sheet content. Our findings identify depoKP36 as a suitable candidate for the development of new treatments for K. pneumoniae infections.
\end{abstract}

Keywords: bacteriophage; Klebsiella sp.; capsule; polysaccharide depolymerase

\section{Introduction}

Klebsiella pneumoniae ranks among the eight most common etiological factors of nosocomial infections, including pneumonia and urinary tract infections, accounting for up to $8 \%$ of all cases [1]. Furthermore, it is the second cause (after Escherichia coli) of both hospital- and community-acquired gram-negative bacteremia [1]. It has been reported that the number of Klebsiella strains harbouring extended spectrum beta-lactamases (ESBLs) and carbapenemases (KPC, MBL, OXA-48), which confer multidrug resistance, has significantly increased in recent years [2-5]. In Europe, the prevalence of ESBL- and KPC-producing Klebsiella among invasive isolates has reached $21 \%$ and $8.3 \%$, respectively. 
One of the most important virulence factors of K. pneumoniae is the polysaccharide, that surrounds the cell and may be organized into a distinct structure termed a capsule (capsular polysaccharide, CPS), or it can be released as an exopolysaccharide (EPS). CPS is a complex of acidic polysaccharide structure composed of repeating subunits of three to six sugars [1], with numerous configurations leading to identify at least 78 distinct CPS types [6-8]. CPS is critical for the resistance of K. pneumoniae to host defense mechanisms, suppression of early inflammatory response, adherence, and biofilm formation [9]. It also impedes or blocks the penetration of certain antibiotics into bacterial cells [10]. Additionally, it can provide a physical barrier to prevent the harmful effects of the environmental conditions, and to limit or preclude phage access [11]. The co-evolution of phages and their host bacteria has resulted in the formation of phage-encoded enzymes that depolymerize the highly specific polysaccharide structures, in order to gain access to the outer membrane and subsequently inject DNA into the bacterium [12,13]. The depolymerase enzymes associated with capsular-targeting phage particles reduce the viscosity of CPS and strip it from the surface of encapsulated bacteria [12]. The majority of Klebsiella acting enzymes randomly attack glycosidic linkages of CPS to release repeating units of the polymer [14-16]. The enzymatic loss of a capsule or alteration of its composition, makes bacteria devoid of an important shield and, therefore, more susceptible. As a result, capsular-targeting phages or their depolymerases in combination with other therapeutic agents could be exploited for the eradication of virulent pathogens.

Multiple applications of depolymerases have been proposed, including determination of Klebsiella capsular types for clinical strains [8,17], production of oligosaccharides from polysaccharides [18,19], or as alternative therapeutic agents to treat Klebsiella infections $[17,20]$. The latter application is of particular importance, as this opportunistic pathogen is a growing concern for public health.

In our previous study, the phage KP36 (vB_KpnS_KP36), whose genome encompasses 49,797 base pairs (bp) encoding 80 gene products, was characterized [21]. Transmission electron microscopy and genome sequence analyses revealed that this phage belongs to the family Siphoviridae, and is currently classified as a member of the "KP36likevirus" genus within subfamily Tunavirinae [22].

In the present work, we proved that the K. pneumoniae phage KP36 expresses an enzyme able to degrade the bacterial capsule and that this activity is conditioned by a tailspike protein with depolymerase activity. We also recombinantly produced this protein and characterized its biochemical properties, structural features in solution, as well as its activity in vitro and in vivo on Galleria mellonella model.

\section{Materials and Methods}

\subsection{Phage, Bacterial Strains, and Culture Conditions}

We originally isolated Klebsiella phage KP36 from biologically-treated sewage in Poland using the K. pneumoniae clinical isolate 486 as the host strain [21]. This phage and bacterial strain have been deposited in the Polish Collection of Microorganisms (Institute of Immunology and Experimental Therapy, Polish Academy of Sciences, Wroclaw, Poland) under accession numbers F/00068 and $\mathrm{B} / \mathrm{F} / 00068$, respectively. They are publicly available from the authors upon request. The phage genome sequence has been deposited in GenBank/EMBL under the accession NC_029099. Besides the host strain, ESBL-producing clinical isolates were also analyzed using the spot method. These included the host strain, nine other strains $(11,27,39,74,77,271,767,1636,7809131)$ belonging to the Institute of Genetics and Microbiology Bacterial Collection (Wroclaw, Poland), and K. pneumoniae 700603 obtained from the American Type Culture Collection (Microbiologics, St. Cloud, MN, USA). The evaluation of capsular type was performed using wzi sequencing according to the method of Brisse et al. [23]. Klebsiella strains were routinely grown in Trypticase Soy Broth or Agar (TSB or TSA, BioMérieux, Marcy-l'Étoile, France) at $37^{\circ}$ C. E. coli strains (Invitrogen, Thermo Fisher Scientific, Waltham, MA, USA) were used: top $10 \mathrm{~F}^{\prime}$ for plasmid propagation and BL21(DE3) for recombinant protein expression. These strains were cultivated in Lysogeny Broth (LB, BioCorp, Warszawa, Poland) at $37^{\circ} \mathrm{C}$. 


\subsection{Cloning, Expression, and Purification}

Bacteriophage KP36 genomic DNA was extracted and purified as previously described [21]. The gp50 open reading frame (ORF; NCBI acc. No. YP_009226010.1) encoding the depolymerase enzyme encoded by Klebsiella phage KP36 (depoKP36) was amplified by PCR using the specific primer

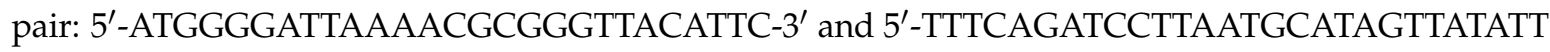
C-3' (Genomed, Warszawa, Poland) and Pfu DNA polymerase (Fermentas, Thermo Fisher Scientific). The 2649 bp PCR amplification product was subsequently cloned into the pEXP5-CT/TOPO ${ }^{\circledR}$ expression vector (Invitrogen, Carlsbad, CA, USA) with a C-terminal His6 tag. Clone integrity was verified by DNA sequencing (Genomed). Following transformation of the correct construct into $E$. coli BL21(DE3) strain, plasmid-bearing cells were grown in $750 \mathrm{~mL}$ of LB supplemented with $100 \mu \mathrm{g} / \mathrm{mL}$ ampicillin at $37^{\circ} \mathrm{C}$ with vigorous agitation to an optical density $\left(\mathrm{OD}_{600 \mathrm{~nm}}\right)$ of $\sim 0.6$. Recombinant protein expression was induced at $20^{\circ} \mathrm{C}$ for $18 \mathrm{~h}$ by the addition of isopropyl- $\beta$-D-thiogalactopyranoside (IPTG) to a final concentration of $0.1 \mathrm{mM}$. Next, the culture was harvested by centrifugation $(5000 \times g$, $\left.20 \mathrm{~min}, 4^{\circ} \mathrm{C}\right)$ and the pellet was resuspended in lysis buffer $(300 \mathrm{mM} \mathrm{NaCl}, 20 \mathrm{mM}$ Tris- $\mathrm{HCl}, 10 \mathrm{mM}$ imidazole, $5 \%(v / v)$ glycerol, $\mathrm{pH} 7.8)$ containing complete protease inhibitor cocktail (Roche Diagnostics, Mannheim, Germany). After sonication, the whole-cell lysate was then centrifuged $(12,500 \times g, 30 \mathrm{~min}$, $4{ }^{\circ} \mathrm{C}$ ) and the soluble fraction was filtered through a $0.22 \mu \mathrm{m}$ filter (Millipore, Darmstadt, Germany). The His-tagged protein purification was performed with a Ni-NTA His·Bind ${ }^{\circledR}$ Resins (Novagen, EMD Millipore, Darmstadt, Germany) in gravity columns or Bio-Scale Mini Profinity IMAC cartridges (Bio-Rad, Hercules, CA, USA) in combination with FPLC-system (Bio-Rad). After column equilibration with the washing buffer ( $300 \mathrm{mM} \mathrm{NaCl}, 20 \mathrm{mM}$ Tris-HCl, $10 \mathrm{mM}$ imidazole, $5 \%$ (v/v) glycerol, $\mathrm{pH} 7.8)$, the lysate was loaded and washed with 15 volumes of washing buffer. The protein was eluted $(300 \mathrm{mM}$ $\mathrm{NaCl}, 20 \mathrm{mM}$ Tris- $\mathrm{HCl}, 150 \mathrm{mM}$ imidazole, $5 \%(v / v)$ glycerol, pH 7.8) and dialyzed overnight at $4{ }^{\circ} \mathrm{C}$ against a 1000-fold volume of phosphate-buffered saline (PBS) buffer (137 mM NaCl, $2.7 \mathrm{mM} \mathrm{KCl}$, $10 \mathrm{mM} \mathrm{Na}_{2} \mathrm{HPO}_{4}, 1.8 \mathrm{mM} \mathrm{KH} \mathrm{PO}_{4}, \mathrm{pH}$ 7.4) using Float-A-Lyzer (Serva, Heilderberg, Germany). Affinity-purified protein was concentrated to $1.5 \mathrm{mg} / \mathrm{mL}$ by centrifugation over a 30-kDa cut-off membrane (Amicon Ultra Centrifugal Filters, Merck Millipore, Darmstadt, Germany). A $0.5 \mathrm{~mL}$ sample was loaded onto a Superdex 200 10/300 column (GE Healthcare, Little Chalfont, UK), equilibrated, and eluted with a buffer containing $150 \mathrm{mM} \mathrm{NaCl}, 20 \mathrm{mM}$ Tris- $\mathrm{HCl}, 2 \%(v / v)$ glycerol $\mathrm{pH} 7.8$ with a constant flow rate of $0.5 \mathrm{~mL} / \mathrm{min}$.

\subsection{Protein Analysis Assays}

Sodium dodecyl sulfate-polyacrylamide gel electrophoresis (SDS-PAGE) was performed according to the method of Laemmli [24] using a $12 \%$ polyacrylamide gel or precast Tris-HCl PAGE gels $(4 \%-20 \%$, gradient polyacrylamide gels, Bio-Rad), after heating the protein samples at $95^{\circ} \mathrm{C}$ for $5 \mathrm{~min}$. To evaluate enzyme susceptibility to SDS and proteolysis, the samples of $30 \mu \mathrm{L}$ containing $250 \mu \mathrm{g} / \mathrm{mL}$ depoKP36 in the buffer ( $50 \mathrm{mM} \mathrm{Na}_{2} \mathrm{HPO}_{4}, \mathrm{pH} 7.0$ ) containing 1\% SDS (Bio-Rad) or 1\% trypsin (Gibco BRL, Paisley, UK) were incubated for $10 \mathrm{~min}$ at room temperature (RT) or $100{ }^{\circ} \mathrm{C}$ and at $37^{\circ} \mathrm{C}$ for $1 \mathrm{~h}$, respectively. Further, the protein samples were mixed with Laemmli buffer (Bio-Rad), and analyzed in SDS-PAGE as heated and unheated samples. For native PAGE, TGX precast gels (Bio-Rad), and running buffer (25 mM Tris, 192 mM glycine, pH 8.3) were used. Sample buffer ( $62.5 \mathrm{mM}$ Tris-HCl, $25 \%$ glycerol, $1 \%$ bromophenol blue, $\mathrm{pH} 6.8)$ was mixed with a protein sample $(1: 1 \mathrm{v} / \mathrm{v})$ and loaded without heating. Molecular weight (MW) standards (10-250 kDa or 6.5-212 kDa) were used (Bio-Rad). The protein bands were visualized by Coomassie brilliant blue R-250 (Bio-Rad) staining.

For zymogram assays, samples were boiled for $5 \mathrm{~min}$ before applying them to a $12 \%$ SDS-PAGE gel, which contained $45 \%(v / v)$ crude EPS from K. pneumoniae. After electrophoresis, the zymograms were washed with MilliQ water at RT and transferred to a buffer $\left(0.15 \mathrm{M} \mathrm{NaH}_{2} \mathrm{PO}_{4}, 10 \mathrm{mM} \mathrm{MgCl}\right.$, and $0.1 \%(w / v)$ Triton $\mathrm{X}-100 ; \mathrm{pH} 7.0)$ for $48 \mathrm{~h}$ at $\mathrm{RT}$ for in situ protein renaturation. Following this, gels were rinsed with MilliQ water, stained with methylene blue $(0.1 \%(v / v), 0.001 \%(w / v) \mathrm{KOH})$ for $12 \mathrm{~h}$ at $\mathrm{RT}$, and then destained with water until enzyme activity bands appeared. 
The protein concentration was measured fluorometrically (Qubit 2.0, Thermo Fisher Scientific) or spectrophotometrically (NanoDrop 2000 Spectrophotometer, Thermo Fisher Scientific) using a molar extinction coefficient of $94,240 \mathrm{~cm}^{-1} \cdot \mathrm{M}^{-1}$ calculated by ProtParam program [25].

\subsection{Extraction and Purification of Exopolysaccharide (EPS)}

To extract and purify EPS, a crude EPS fraction was prepared from supernatants of five-day K. pneumoniae 486 cultures, according to the method of Bales et al. [26]. Briefly, $200 \mathrm{~mL}$ of TSB was inoculated with $20 \mathrm{~mL}$ of an overnight culture of $\mathrm{K}$. pneumoniae and incubated at $37{ }^{\circ} \mathrm{C}$ without agitation for 5 days. Following the addition of $60 \mu \mathrm{L}$ formaldehyde ( $36.5 \%$ solution) to each $10 \mathrm{~mL}$ of culture for $1 \mathrm{~h}$ and then $1 \mathrm{M} \mathrm{NaOH}$ for $3 \mathrm{~h}$ at RT, with agitation, the secreted EPS was separated from bacterial cells by centrifugation $\left(16,800 \times g, 1 \mathrm{~h}, 4^{\circ} \mathrm{C}\right)$. The proteins and nucleic acids were precipitated by adding of trichloroacetic acid (TCA; $20 \% w / v)$ and subsequently centrifuging the solution $(16,000 \times g$, $1 \mathrm{~h}, 4^{\circ} \mathrm{C}$ ). The pellet was discarded and EPS remaining in the supernatants was precipitated away from lipids by adding 1.5 volumes of $96 \%$ cold ethanol at $-20{ }^{\circ} \mathrm{C}$ for $24 \mathrm{~h}$. The precipitate was collected by centrifugation $\left(16,800 \times g, 1 \mathrm{~h}, 4^{\circ} \mathrm{C}\right)$ and resuspended in MilliQ water. The crude EPS was dialyzed against an excess of MilliQ water for $24 \mathrm{~h}$ at $4{ }^{\circ} \mathrm{C}$ using a 12-14 $\mathrm{kDa}$ molecular weight cut-off (MWCO) membrane (Serva, Heidelberg, Germany) to remove low molecular weight impurities, and the remaining retentate was lyophilized overnight. Next, the lyophilized powder was resuspended in $5-10 \mathrm{~mL}$ of water to a final concentration of $4 \mathrm{mg} / \mathrm{mL}$.

\subsection{Functional Assays}

To visualize the enzyme activity, identifying the sensitivity of Klebsiella strains and comparing it to phage-mediated lysis, spot assay was used. For this purpose, log-phase bacteria were transferred directly onto TSA plates. After drying, both $10 \mu \mathrm{L}$ of serially diluted recombinant enzyme or $10 \mu \mathrm{L}$ the phage suspension $\left(10^{8} \mathrm{PFU} / \mathrm{mL}\right)$ was spotted onto the bacterial lawn. After overnight incubation at $37^{\circ} \mathrm{C}$, plates were observed for formation of clear zones (halo) or lytic zones (plaque) surrounded by a halo, respectively. For determination of bacterial count both in the halo zone and bacterial lawn, at least two equal square agar blocks $(5 \mathrm{~mm} \times 5 \mathrm{~mm}$ ) were cut out from each zone from three different plates. Each block was suspended in $1 \mathrm{~mL}$ of PBS and vortexed. The number of bacteria was counted after plating a dilution series of the supernatant. Bacterial cell viability after depoKP36 treatment was also evaluated. Briefly, the log-phase bacteria $\left(\sim 2 \times 10^{8} \mathrm{CFU} / \mathrm{mL}\right)$ were incubated with the enzyme (final concentration $280 \mu \mathrm{g} / \mathrm{mL}$ ) for $2 \mathrm{~h}$ at $37^{\circ} \mathrm{C}$. The number of viable bacteria were determined at the beginning and, afterwards, exposed to enzyme by serial dilution in PBS followed by overnight growth at $37^{\circ} \mathrm{C}$ on TSA plates.

The activity of depoKP36 at various pH levels (ranging from 3.0 to 9.0) and at various temperatures (ranging from $20-80^{\circ} \mathrm{C}$ ) was assessed by measuring the decrease in turbidity according to the method reported by Belleman et al. [27] with some modifications. Briefly, aqueous EPS solution extracted from K. pneumoniae $486(4 \mathrm{mg} / \mathrm{mL})$, was dissolved in an appropriate buffer to final concentration $0.5 \mathrm{mg} / \mathrm{mL}$. The enzyme reaction was initiated by adding $115 \mu \mathrm{L}$ of enzyme to $996 \mu \mathrm{L}$ of substrate solution. The mixture was incubated for $30 \mathrm{~min}$ at the desired buffer or temperature and then cooled. Remaining polysaccharides were precipitated by adding cetylpyridinium chloride (CPC; Sigma-Aldrich, St. Louis, MO, USA) to a final concentration of $5.1 \mathrm{mg} / \mathrm{mL}$. After $10 \mathrm{~min}$ incubation at RT, the absorbance at $600 \mathrm{~nm}$ was measured (Asys UVM340, Biochrom Ltd., Cambourne, UK). Relative enzyme activity was calculated and was expressed as percent reduction of turbidity compared with control without enzyme. The influence of $\mathrm{pH}$ on enzyme activity was determined at $20^{\circ} \mathrm{C}$ using the following buffers: $50 \mathrm{mM}$ sodium acetate buffer ( $\mathrm{pH} 3.0-5.0), 50 \mathrm{mM} \mathrm{Na}_{2} \mathrm{HPO}_{4}(\mathrm{pH}$ 6.0-7.0), and $50 \mathrm{mM}$ Tris- $\mathrm{HCl}$ buffer ( $\mathrm{pH} 8.0-9.0$ ). To study the effect of temperature on enzyme activity, assays were performed in $50 \mathrm{mM}$ sodium acetate buffer ( $\mathrm{pH} 5.0$ ) in the range $20-80^{\circ} \mathrm{C}$. For the measurement of time evolution of enzyme activity at different temperatures, depoKP36 was pre-incubated at the desired temperature in buffer at pH 5.0 and samples were taken at regular time intervals $(0,10,20,30,40,50$, and $60 \mathrm{~min})$. After cooling 
the samples, residual activity was determined at $20^{\circ} \mathrm{C}$ using the standard protocol described above. Each experiment was performed in quadruplicate and repeated at least twice.

\subsection{Galleria Mellonella Larvae Infection Model}

Wax moth larvae (G. mellonella) were obtained from a culture of insects. Briefly, the larvae were reared on a natural diet-honeybee nest debris at $30^{\circ} \mathrm{C}$ in the dark. Prior to inoculation, the last instar larvae were selected to be similar in size (approximately $250-350 \mathrm{mg}$ ) and were then maintained on wood chips in darkness at $15^{\circ} \mathrm{C}$ for 3-4 days. Bacteria from overnight culture were grown in TSB at $37^{\circ} \mathrm{C}$ to log-phase for $2 \mathrm{~h}$, harvested $\left(5000 \times g, 20 \mathrm{~min}, 4^{\circ} \mathrm{C}\right)$, washed with PBS and suspended in PBS to an optical density at $600 \mathrm{~nm}$ of 1.0 corresponding to $\sim 10^{9} \mathrm{CFU} / \mathrm{mL}$. Larvae were inoculated with $10 \mu \mathrm{L}$ of bacterial suspension containing $10^{7} \mathrm{CFU}$ into the last pro-leg using insulin syringe with a 30-gauge needle (NIO Lab, Nieborow, Poland). The anti-virulence effect of enzyme on K. pneumoniae 486 was estimated by inoculated larvae with either bacteria pretreated with depoKP36 (final concentration, $280 \mu \mathrm{g} / \mathrm{mL}$ ) for $2 \mathrm{~h}$ at $37^{\circ} \mathrm{C}$, or enzyme administered within $5 \mathrm{~min}$ after untreated bacterial infection. Three control groups were used: uninfected larvae, larvae injected with PBS to monitor the killing due to injection trauma, and larvae injected with depoKP36 to assess the toxicity of the enzyme. After inoculation, caterpillars were kept at $37^{\circ} \mathrm{C}$ in the dark for $72 \mathrm{~h}$. The results were expressed as the percentage survival rate estimated on the basis the touch-provoked motility and the appearance of pigmentation at $24 \mathrm{~h}, 48 \mathrm{~h}$, and $72 \mathrm{~h}$ post injection. For each option, at least three independent experiments were performed (10 larvae per trial). Survival curves were plotted using the Kaplan-Meier method, and the analysis in survival was performed by using the log-rank Mantel-Cox (GraphPad Software, Inc., La Jolla, USA). A $p$-value of $<0.05$ was considered to be statistically significant.

\subsection{Antimicrobial Susceptibility Testing}

K. pneumoniae strains (486 and 77) susceptibility to the antibiotics representing four different classes: aminoglycosides (gentamicin sulfate; MP Biomedicals, Eschwege, Germany), fluoroquinolones (ciprofloxacin; MP Biomedicals, Eschwege, Germany), tetracyclines (oksytetracycline; MP Biomedicals, Eschwege, Germany), and chloramphenicol (Calbiochem, Darmstadt, Germany), was determined by a broth microdilution technique according to Clinical and Laboratory Standards Institute (CLSI) recommendations [28]. For quality control, K. pneumoniae ATCC 700603 was included in each set of tests. The minimal inhibitory concentration (MIC) was determined as the lowest antibiotic concentration at which there is no visible growth.

To evaluate the activity of depoKP36 combined with antibiotics against K. pneumoniae strains, the checkerboard broth microdilution method was used. Two-fold serial dilutions of the antibiotic, in a range between 2 MIC and 1/4 MIC, and two-fold serial dilutions of the enzyme (final concentrations from $125 \mu \mathrm{g} / \mathrm{mL}$ to $7.81 \mu \mathrm{g} / \mathrm{mL}$ ) were prepared for every option tested and $100 \mu \mathrm{L}$ aliquots of each component was added into the wells of the sterile 96-well microtiter plate (VWR International, Darmstadt, Germany), along the ordinary and abscissa, respectively. Then each well was inoculated with $10 \mu \mathrm{L}$ of a bacterial inoculum of $5 \times 10^{5} \mathrm{CFU} / \mathrm{mL}$, and the plates were incubated at $37^{\circ} \mathrm{C}$ for $18 \mathrm{~h}$. The MIC was determined as the lowest concentrations of antibiotic in combination with the enzyme giving complete inhibition of visible growth.

\subsection{Light Scattering Experiments}

Purified, not aggregated depoKP36 was analyzed by size-exclusion chromatography (SEC) coupled to a miniDAWN TREOS multi-angle static light scattering (MALS) detector (Wyatt Instrument Technology Corp., Santa Barbara, CA, USA) and an OptilabTM rEX (Wyatt Instrument Technology Corp.). The protein sample of $2 \mathrm{mg}$ was loaded on a S200 10/30 column, previously equilibrated in $200 \mathrm{mM} \mathrm{NaCl}, 25 \mathrm{mM}$ HEPES, $5 \%$ glycerol, $\mathrm{pH} 7.8$. A constant flow rate of $0.5 \mathrm{~mL} / \mathrm{min}$ was applied. The online measurement of the intensity of the Rayleigh scattering as a function of the angle as well as 
the differential refractive index of the eluting peak in SEC was used to determine the average MW of eluted protein using Astra 5.3.4.14 (Wyatt Instrument Technology Corp.) software.

\subsection{Circular Dichroism (CD) Studies}

Circular dichroism (CD) spectroscopy and thermal melting curves were recorded on a Jasco J-810 spectropolarimeter fitted with a single cell Peltier temperature controller (Model PTC-423S). CD measurements were carried out at $20^{\circ} \mathrm{C}$ in a $0.1 \mathrm{~cm}$ optical path length cell with protein concentration of $0.2 \mathrm{mg} / \mathrm{mL}$ in $20 \mathrm{mM}$ sodium acetate buffer (pH 6.0) containing $150 \mathrm{mM} \mathrm{NaCl}$. Each spectrum was scanned from $260 \mathrm{~nm}$ to $190 \mathrm{~nm}$ with an integration time of $3 \mathrm{~s}$ at each wavelength. All spectra were averaged from three scans and baseline-corrected using a blank consisting of sodium acetate buffer (20 mM, pH 6.0). The molar ellipticity per mean residue, $[\Theta]$ in $\mathrm{deg} \cdot \mathrm{cm}^{2} \cdot \mathrm{dmol}^{-1}$, was calculated from the following equation: $[\Theta]=[\Theta]$ obs $\times$ mrw $\times(10 \times 1 \times C)^{-1}$ where $[\Theta]$ obs is the ellipticity measured in degrees, mrw is the mean residue molecular mass (106.5 Da), 1 is the optical path length of the cell in $\mathrm{cm}$, and $\mathrm{C}$ is the protein concentration in $\mathrm{g} / \mathrm{L}$. Thermal denaturation studies were conducted at $214 \mathrm{~nm}$ with increasing temperature from $20{ }^{\circ} \mathrm{C}$ to $90^{\circ} \mathrm{C}$. The protein solution was equilibrated at each temperature point for $2 \mathrm{~min}$, and the temperature was increased with an average rate of $0.5^{\circ} \mathrm{C} / \mathrm{min}$. The melting temperature $(\mathrm{T} m)$ was obtained by taking the peak of the first derivative of the melting curve. The data were then normalized, and the T $m$ was inferred from the loss of $50 \%$ of the maximum signal.

\section{Results}

\subsection{Identification of Phage KP36 gp50 as a Putative EPS Depolymerase}

The ability of bacteriophages to enzymatically degrade bacterial polysaccharides is an effective strategy allowing the virions to deliver their genome across the bacterial envelope to the cell cytoplasm, where their genetic information is expressed and replicated. While studying the phage KP36, we noticed the appearance of hazy, expanding halo zones surrounding plaques with a small clear center formed by it on a bacterial lawn [21]. This observation indicated that phage KP36 may produce a virion-associated polysaccharide-degrading enzyme.

Protein Blast (BlastP) analysis of the gp50 gene product (putative tailspike protein) showed high sequence identity of the N-terminal region to the tail fiber protein of Klebsiella phage Sushi and hypothetical phage proteins of Klebsiella phage 1513, Enterobacter phage F20 and Klebsiella phage KLPN1 (Figure 1a) [29]. Moreover, the C-terminal region has significant sequence identity to Klebsiella phage KP34 gp57. Amino acid sequence also evidenced a fragment exhibiting similarity to the pectate lyase superfamily (residues 263-330). Of note, none of the aforementioned phage proteins has yet been characterized in vitro.

Whereas no significant sequence similarity with structurally determined proteins was found using BlastP, sequence comparisons using consensus sequence methods by HHPred identified two moderate homologs in the Protein Data Bank (PDB) database [30]. Those included a pre-neck appendage protein from Bacillus phage phi29 (pdb code 3gq8) and polygalacturonase II from Aspergillus niger (pdb code $1 \mathrm{bhe}$ ), (Figure 1b). Both proteins contain high $\beta$-helical structure. Consistently, secondary structure predictions using PSIPRED [31] indicate that gp50 of phage KP36 possesses a dominant amount of beta-structure (53\%), similar to other identified polysaccharide binding enzymes of viral or microbial origins [32,33].

All of this information suggested that the product of gene gp50 is a probable polysaccharide depolymerase involved in the phage attack against its host bacterium. Therefore, we cloned, expressed, and purified the full-length protein (883 amino acids) with predicted molecular mass of $93.4 \mathrm{kDa}$ and a $\mathrm{pI}$ of 5.0, here designated as depoKP36, to gather understanding on its functional and structural properties. 


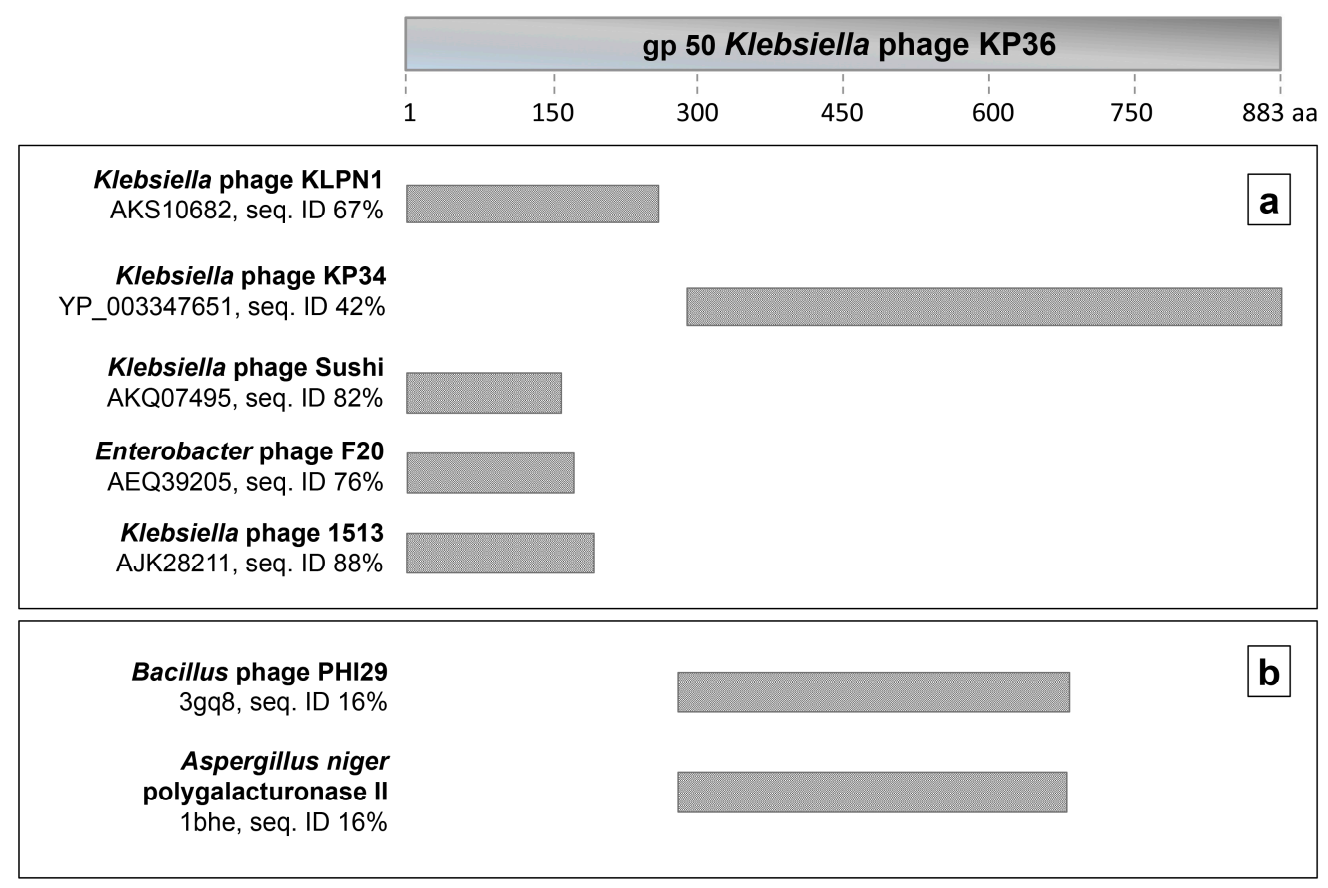

Figure 1. Bioinformatic analysis of Klebsiella phage KP36. (a) BlastP analysis in non-redundant sequence database; (b) HHPred analysis in Protein Data Bank (PDB).

3.2. Recombinant depolymerase enzyme encoded by Klebsiella phage KP36 (depoKP36) Degrades Bacterial EPS and Shows a Narrow Spectrum Activity Against Specific K. pneumoniae Strains

The recombinant depoKP36 was purified in the two-step strategy coupling nickel affinity and gel filtration procedures (Figure 2). The size-exclusion chromatography profile indicated that the purified protein was predominantly homogeneous, with only a small proportion in an aggregated state. Only fractions involving the main peak corresponding non-aggregated protein were pooled and subjected to further studies. The purified depoKP36 migrated as a single band on SDS-PAGE corresponding to an approximately $93.4 \mathrm{kDa}$ protein.

The activity of depoKP36 was tested on K. pneumoniae 486 lawn by spot assay with halo zone detection using enzyme dilutions ranging from $50 \mu \mathrm{g} / \mathrm{mL}$ to $3.1 \mu \mathrm{g} / \mathrm{mL}$ (Figure 3a). The capsular staining of bacteria present in and outside of zone indicated the degradation of capsular material. The presence of almost equal amounts of viable cells in samples from both areas $\left(2.9 \times 10^{9} \pm 3.0 \times 10^{8} \mathrm{CFU} / \mathrm{mL}\right.$ and $3.6 \times 10^{9} \pm 3.5 \times 10^{8} \mathrm{CFU} / \mathrm{mL}$, respectively) suggested the lack of affected cell viability.

To confirm that depoKP36 acts as polysaccharide depolymerase, we subsequently extracted and purified EPS from supernatants of host culture and applied zymography analysis to visualize its enzymatic activity. As shown in Figure 3b, a single band of clearing at $\sim 94 \mathrm{kDa}$, which corresponds to the size of the complete depoKP36 protein, was observed on zymograms. The same band was seen after phage KP36 application.

Enzymatic activity of depoKP36 was further tested on clinical K. pneumoniae strains panel using spot test. The phage KP36 was included as a positive control. Among the 11 strains tested, eight (73\%) isolates corresponded to the K63 reference strain, the others represented the three other capsular types, namely K3, K10 and K20. Only K63 type bacteria proved to be susceptible to CPS degradation by both the protein and phage, whereas none of the other aforementioned capsular types were as sensitive. 


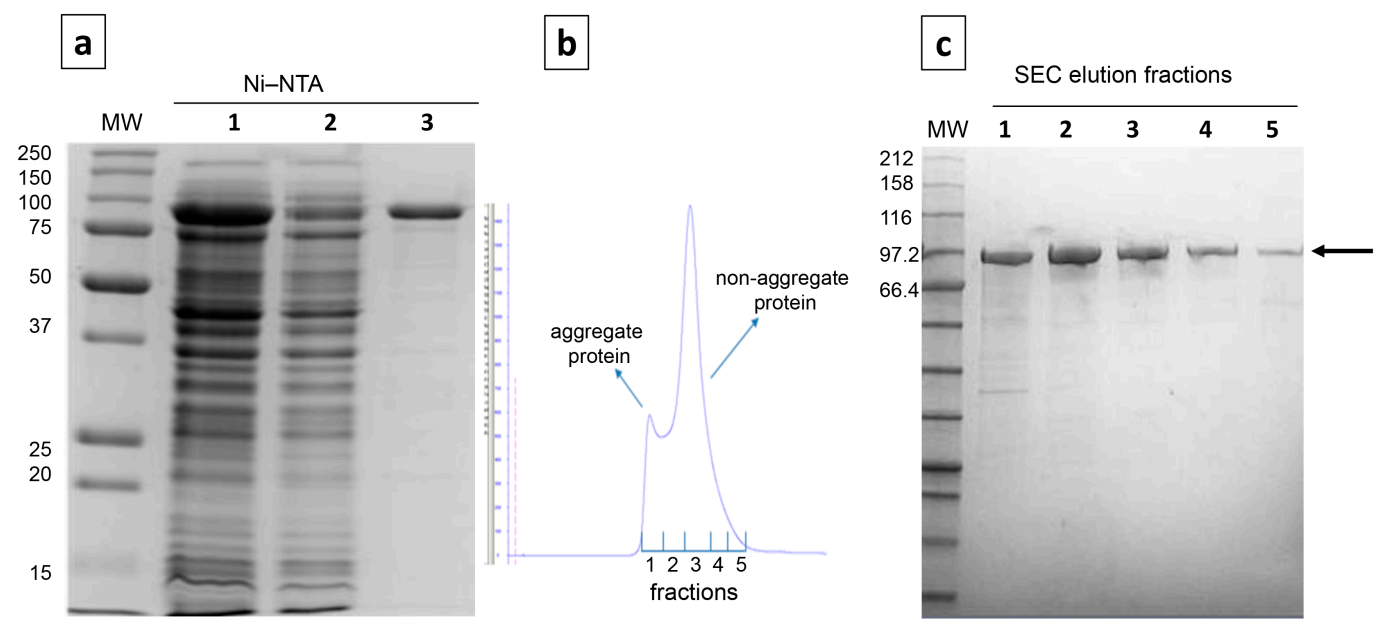

Figure 2. Expression and purification of the depolymerase enzyme encoded by Klebsiella phage KP36 (depoKP36); (a) Ni-NTA His·Bind®Resins affinity column purification. Protein samples run on a reducing $12 \%$ gel. Lane MW: molecular weight (MW) markers; lane 1: lysate of induced E. coli BL21 pEXP-5-CT/TOPO ${ }^{\circledR}$-depoKP36 cells; lane 2: column wash with buffer containing $10 \mathrm{mM}$ imidazole; lane 3: eluted proteins; (b) Gel filtration chromatogram; (c) Eluted protein after gel filtration chromatography. Protein samples were separated on 4-20\% sodium dodecyl sulfate-polyacrylamide gel electrophoresis (SDS-PAGE) gel. Lane MW: MW markers; lane 1: aggregate protein; lanes 2, 3, 4, 5: non-aggregate protein fractions. Samples were stained using Coomassie brilliant blue R-250. The arrow indicates protein of interest, depoKP36; SEC: size-exclusion chromatography.
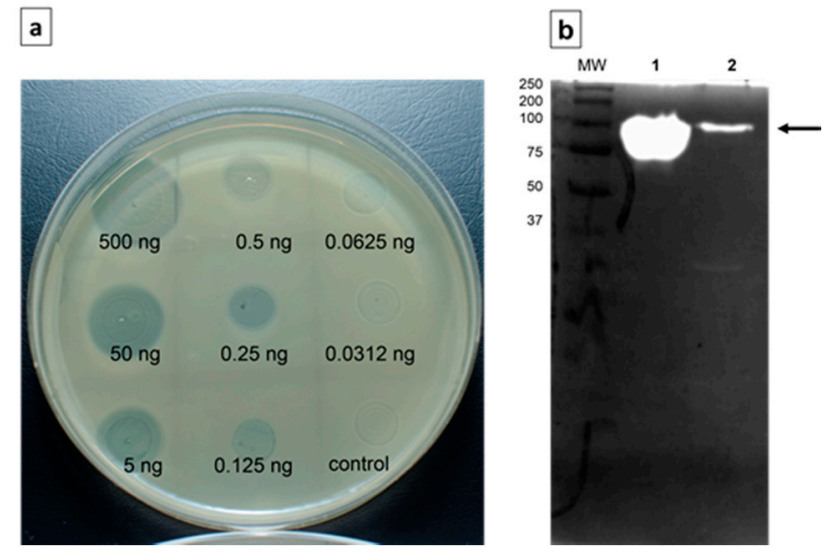

Figure 3. The activity of depoKP36 for its natural substrate. (a) Spot test with serial dilutions of depoKP36 on host strain. Phosphate-buffered saline (PBS) was used as a control; (b) Zymography. Protein samples run on a $12 \%$ standard Laemmli SDS-PAGE gel containing crude exopolysaccharide (EPS) as a substrate. Zymograms were stained with methylene blue. Lane MW: MW markers; lane 1: recombinant depoKP36 (2.5 $\mathrm{g}$ /lane); lane 2: phage KP36 (109 PFU/lane).

\subsection{Anti-Virulence Efficacy of depoKP36 in the G. mellonella Infection Model}

Given the therapeutic efficacy of depolymerase in murine model of K. pneumoniae infections [17] and the capsule necessity for K. pneumoniae virulence in G. mellonella larvae [34], we evaluated the virulence of depoKP36-treated Klebsiella strain as well as the efficacy of treatment with this enzyme in vivo using the insect model. Without the treatment, $100 \%$ of the larvae died within $24 \mathrm{~h}$ after inoculation of $10^{7}$ cells of K. pneumoniae 486 (Figure 4). In contrast, a single dose of enzyme given within $5 \mathrm{~min}$ after bacteria injection as well as inoculation of bacteria pretreated with depoKP36 for $2 \mathrm{~h}$, significantly inhibited K. pneumoniae-induced death in a time-dependent manner $(p<0.003)$. 
At $24 \mathrm{~h}$ and $48 \mathrm{~h}$ post application of depoKP36, the survival rate of Galleria increased by up to $40 \%$ and $30 \%$, respectively. At $72 \mathrm{~h}$ another $10 \%$ of the remaining survivors were dead. In turn, bacteria treated with depoKP36 prior to inoculation killed only $23 \%$ of the larvae at $24 \mathrm{~h}$ compared to $53 \%$ and $57 \%$ mortality at $48 \mathrm{~h}$ and $72 \mathrm{~h}$, respectively. No mortality of larvae was observed in the controls, upon injection of PBS buffer or depoKP36. No differences in the number of viable bacteria were detected before $\left(2.58 \times 10^{8} \mathrm{CFU} / \mathrm{mL} \pm 5.12 \times 10^{7} \mathrm{CFU} / \mathrm{mL}\right)$ and $2 \mathrm{~h}$ after exposure to depoKP36 $\left(2.8 \times 10^{8} \mathrm{CFU} / \mathrm{mL} \pm 4.07 \times 10^{7} \mathrm{CFU} / \mathrm{mL}\right)$.

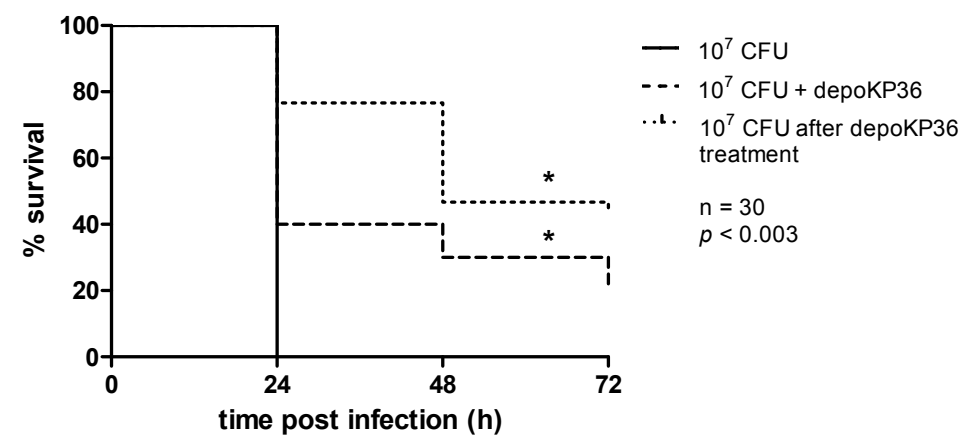

Figure 4. Inhibition of K. pneumoniae-induced mortality by depoKP36 using G. mellonella model. Larvae $(n=30)$ were injected with either bacteria ( $10^{7}$ CFUs/per larvae), enzyme (final concentration, $280 \mu \mathrm{g} / \mathrm{mL}$ ) administered within $5 \mathrm{~min}$ after untreated bacteria inoculation, or depoKP36-treated bacteria, and monitored for mortality. The experiments were controlled by observation of uninfected larvae, PBS-injected larvae and larvae receiving the enzyme only. Survival for each control group was $100 \%$, so for simplicity, these groups were not included in the figure. Survival curves were plotted using the Kaplan-Meier method, and differences in survival were calculated by using the log-rank test (GraphPad); * $p<0.003$ (considered to be statistically significant); Results are the means of at least three independent experiments.

\subsection{DepoKP36 Do Not Affect the Action of Antibiotics Against K. pneumoniae Strains}

To gain further insight of the therapeutic potential of depoKP36, we evaluated the activity of the enzyme in combination with four classes of antibiotics against two K. pneumoniae strains (486 and 77) representing the $\mathrm{K} 63$ capsular type. The MIC values have not changed for each particular antibiotic after depoKP36 application indicating that depolymerase did not alter the potency of any antibiotics tested. The ciprofloxacin, oxytetracycline, and chloramphenicol MICs for both Klebsiella strains were $0.125-0.25 \mu \mathrm{g} / \mathrm{mL}, 1 \mu \mathrm{g} / \mathrm{mL}$, and $2 \mu \mathrm{g} / \mathrm{mL}$, respectively, whereas the MIC of gentamicin was $0.5 \mu \mathrm{g} / \mathrm{mL}$ for strain 486 and $>32 \mu \mathrm{g} / \mathrm{mL}$ for strain 77 .

\subsection{DepoKP36 Remains Stable at Moderately Acidic Conditions and Is Mesophilic}

A quantitative measure of the enzymatic activity of depoKP36 in a range of $\mathrm{pH}$ and temperatures was obtained by monitoring the decrease of turbidity of aqueous solutions of EPS extracted from K. pneumoniae $486(0.5 \mathrm{mg} / \mathrm{mL})$ following the enzyme action (Figure 5). Relative enzyme activity was expressed as percent reduction of turbidity compared with the control without enzyme. The activity range of depoKP36 on its natural substrate as a function of either $\mathrm{pH}$ or temperature was determined after $30 \mathrm{~min}$ incubation in the proper buffer. As a result, we observed that depoKP36 remains active over a $\mathrm{pH}$ range, from 4.0 to 7.0 , with relative activities ranging from $97.1 \% \pm 1.02 \%$ to $97.8 \% \pm 0.57 \%$. The activity diminished substantially as the $\mathrm{pH}$ was lowered below 4.0 or raised above 7.0 , to $54.6 \% \pm 2.81 \%$ and $14.0 \% \pm 14.17 \%$ of initial activity, respectively. Based on these results, depoKP36 can be considered an acidically stable enzyme. Therefore, the enzyme activity at pH 5.0 in the temperature range from $20^{\circ} \mathrm{C}$ to $80^{\circ} \mathrm{C}$ was investigated. Optimal activity of the enzyme was found at temperatures ranging from $20^{\circ} \mathrm{C}$ to $37^{\circ} \mathrm{C}$, which probably reflect adaptation to the physiological 
environment of the K. pneumoniae bacteria. Non-significant reduction, to $95 \%$ of the initial activity, was observed at $45^{\circ} \mathrm{C}$, whereas heat treatments at $56^{\circ} \mathrm{C}$ and $62^{\circ} \mathrm{C}$ lowered the enzyme relative activity to $70 \%$. When heated at $70{ }^{\circ} \mathrm{C}$, the enzymatic activity of depoKP36 fell below $60 \%$ of the initial activity. At higher temperatures, depoKP36 was completely inactivated.
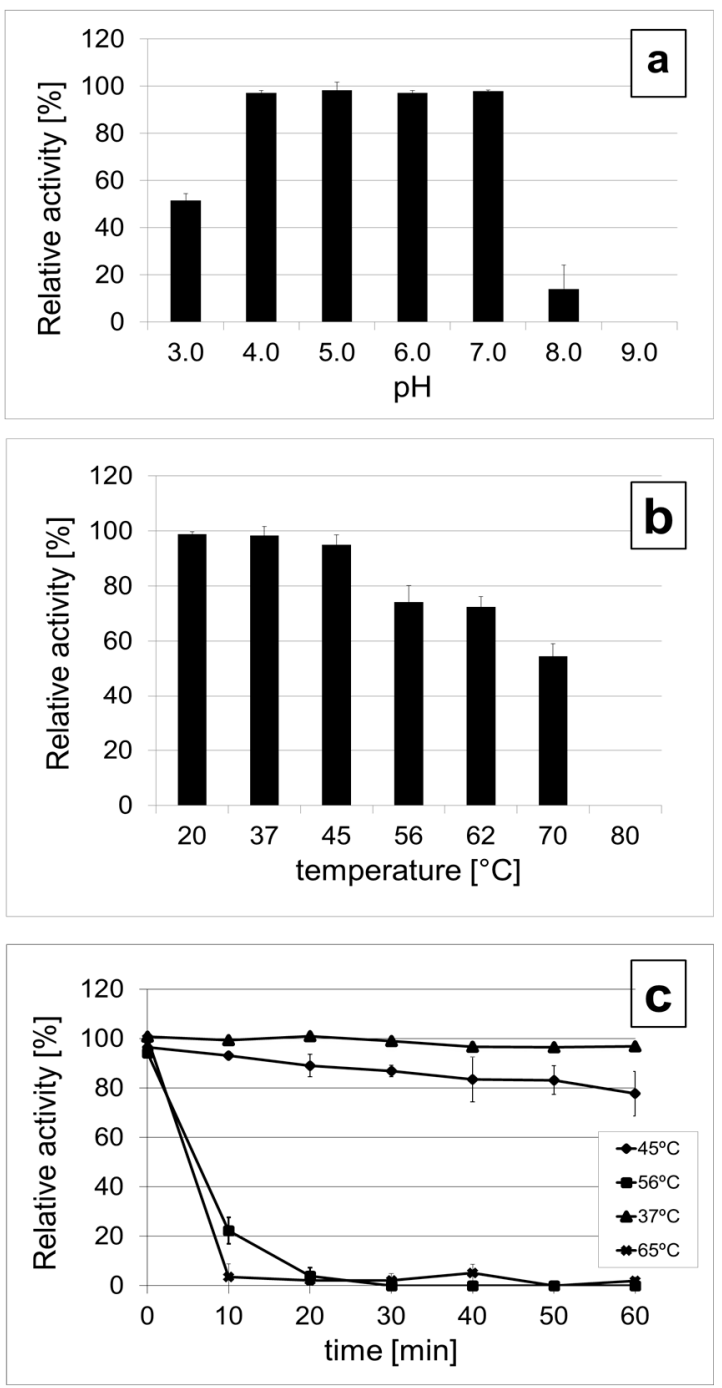

Figure 5. EPS-degrading activity of depoKP36. (a) Effect of $\mathrm{pH}$ on the activity of depoKP36. The optimal $\mathrm{pH}$ was determined at $37^{\circ} \mathrm{C}$ in $50 \mathrm{mM} \mathrm{CH}_{3} \mathrm{COONa}-\mathrm{HCl}$ buffer (pH 3.0-5.0), $50 \mathrm{mM} \mathrm{Na}_{2} \mathrm{HPO}_{4}$ buffer (pH 6.0-7.0), and $50 \mathrm{mM}$ Tris- $\mathrm{HCl}$ buffer ( $\mathrm{pH}$ 8.0-9.0); (b) Influence of various temperatures on the activity of depoKP36 at pH 5.0; (c) Time evolution of depoKP36 activity at $37^{\circ} \mathrm{C}, 45{ }^{\circ} \mathrm{C}, 56{ }^{\circ} \mathrm{C}$ and $65^{\circ} \mathrm{C}$. Enzyme was pre-incubated in the absence substrate for 10, 20, 30, 40, 50, and $60 \mathrm{~min}$ at desired temperature before measuring its activity. Relative enzyme activity was calculated and is expressed as a percent reduction of turbidity compared with control without depoKP36. Each experiment was performed in quadruplicate and repeated at least twice. The data represent means \pm standard deviation (SD).

To gain further insight into the effect of temperature on enzyme activity in solution, depoKP36 was preincubated without the substrate at different temperatures (from $37^{\circ} \mathrm{C}$ to $65^{\circ} \mathrm{C}$ ) in a buffer at $\mathrm{pH}$ 5.0, and the samples were drawn at various time points. The incubation at $37^{\circ} \mathrm{C}$ has no effect on relative turbidity whereas time evolution of turbidity measurements at $45^{\circ} \mathrm{C}$ shows a small decrease $(77.6 \% \pm 9.0 \%)$ after $60 \mathrm{~min}$ of incubation. The decrease of turbidity becomes drastic at $56{ }^{\circ} \mathrm{C}$ and 
$65{ }^{\circ} \mathrm{C}$, with complete suppression after 30 and $10 \mathrm{~min}$, respectively. Altogether, these data show that depoKP36 is active in a wide range of temperatures, from $20^{\circ} \mathrm{C}$ to $45^{\circ} \mathrm{C}$.

\subsection{Structural Characterization of depoKP36 in Solution}

A search of the PDB database identifies polygalacturonase II from Aspergillus niger (seq id 13\% on residues 206-383) as the protein of known structure most similar to depoKP36. Due to this scarce available structural information, we carried out structural studies in solution using CD and light scattering experiments. CD spectra showed that depoKP36 adopts a well-folded conformation, with a negative dichroic minimum between 210 and $220 \mathrm{~nm}$ and a positive dichroic maximum between 195 and $200 \mathrm{~nm}$, characteristic of a protein with high $\beta$-sheet content (Figure 6a). To investigate the heat-induced changes in the protein secondary structure, thermal unfolding curves were achieved by following the CD signal at $214 \mathrm{~nm}$ as a function of temperature. Thermal unfolding curves show a sigmoidal transition with melting temperature $(\mathrm{T} m)=65^{\circ} \mathrm{C}$ (Figure 6b).

a

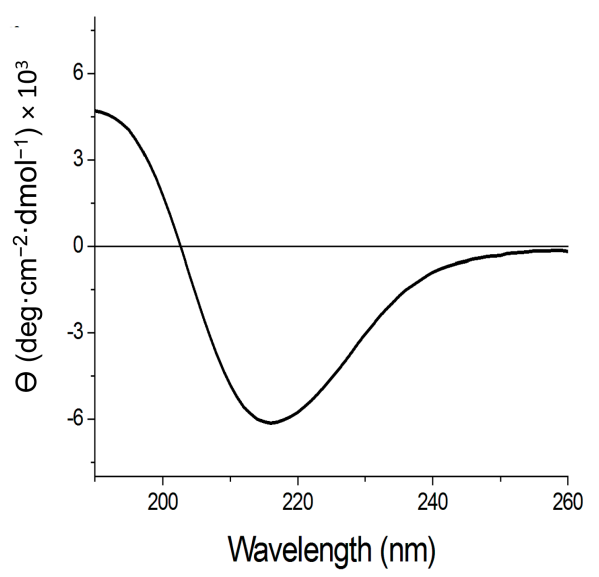

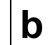

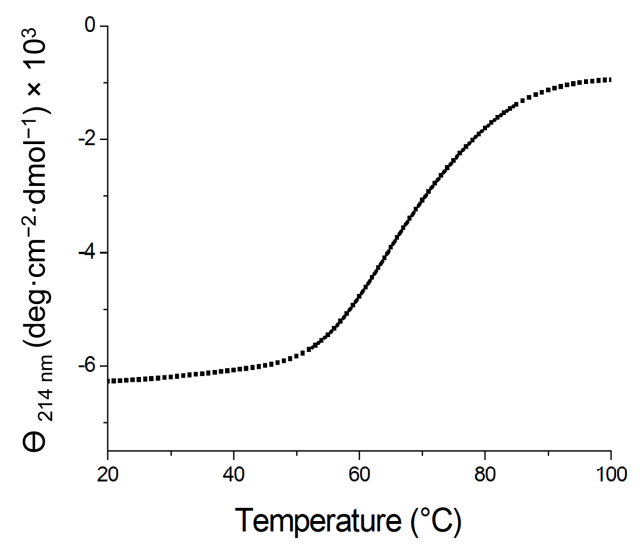

Figure 6. (a) Circular dichroism (CD) spectrum of depoKP36 $(0.2 \mathrm{mg} / \mathrm{mL})$ in sodium acetate $20 \mathrm{mM}$, $\mathrm{pH}$ 6.0; (b) Thermal denaturation curve measured at $214 \mathrm{~nm}$. The midpoint of the curve was used to calculate the melting transition temperatures $(\mathrm{T} m)$ for protein.

Analytical SEC, coupled with MALS (SEC-MALS), was carried out to investigate the oligomerization state of depoKP36 in solution. The online measurement of the intensity of the Rayleigh scattering as a function of the angle as well as the differential refractive index of the eluting peak in SEC was used to determine the MW (Figure 7a). This analysis produced an MW of $255 \mathrm{kDa}$, which corresponds to a trimeric organization of the protein in solution. This MW was also confirmed by native gel electrophoresis (Figure $7 \mathrm{~b}$ ).

Furthermore, to analyze the structural integrity of depoKP36 in the presence of both anionic detergent and protease, the electrophoretic mobility of the enzyme was studied. As shown in Figure 8, depoKP36 migrated as a monomer at $94 \mathrm{kDa}$ during SDS-PAGE regardless of SDS-treated sample heating, which indicates that SDS is sufficient for enzyme denaturation. In turn, the lack of a visible band reflecting this protein on the gel after trypsin treatment suggests its vulnerability to proteolytic cleavage. 

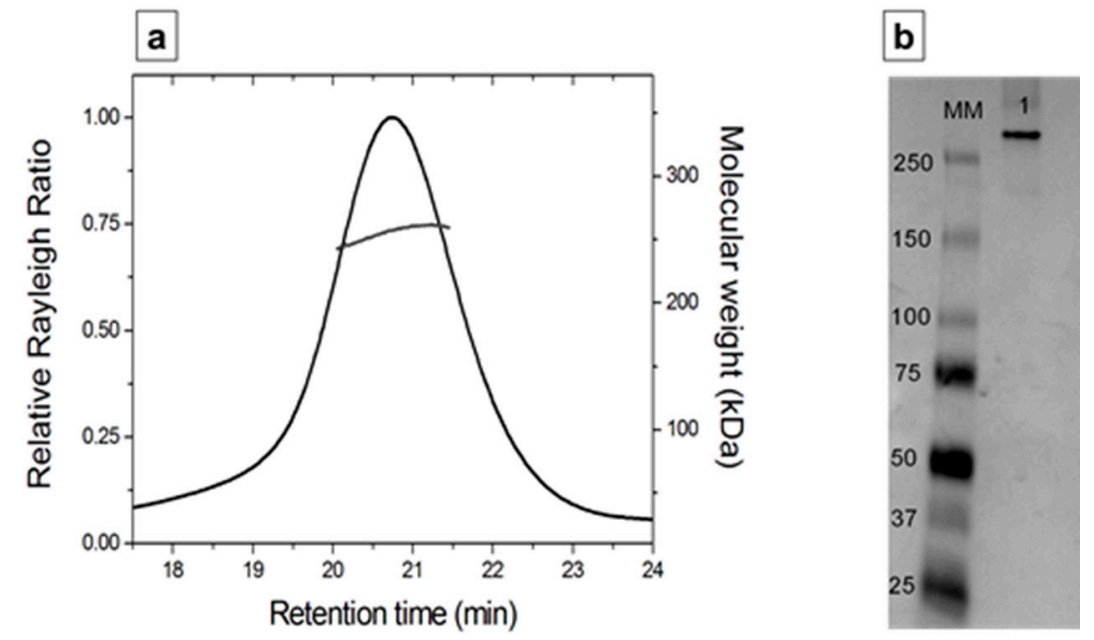

Figure 7. (a) Analytical SEC, coupled with multi-angle static light scattering (MALS) of depoKP36. The black curve represents the Rayleigh ratio (left scale) against the retention time. Molecular mass (right scale) values correspond to a trimeric state; (b) Native PAGE electrophoresis of depoKP36. Lane MM: molecular weight markers, lane 1: recombinant depoKP36.

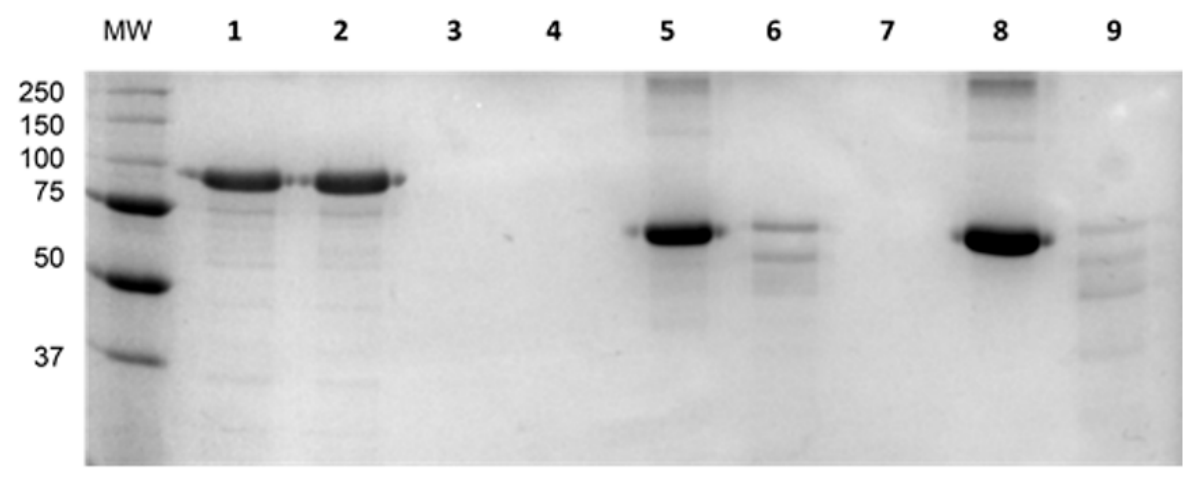

Figure 8. Susceptibility of depoKP36 to denaturation in the presence of $1 \%$ SDS and proteolysis. Lane MW: molecular weight markers; lanes: (1) depoKP36 boiled, (2) depoKP36 non-boiled, (3) depoKP36 + trypsin, boiled, (4) depoKP36 + trypsin, non-boiled, (5) BSA boiled, (6) BSA + trypsin, boiled, (7) trypsin boiled, (8) BSA non-boiled, (9) BSA + trypsin, non-boiled.

\section{Discussion}

Given the crucial role of the CPS in the pathogenesis of Klebsiella infections, it is not surprising that the potential of phage-encoded proteins with polysaccharide depolymerization activity to generate "capsule-stripped" strains has been the subject of extensive studies [17,20,35-38]. Such enzymes can sensitize the bacterial cells making them more susceptible to a component of the host's immune system as well as to antimicrobials [39,40]. The other advantages of these proteins are the low incidence of resistance generation and lack of side effects on normal microbiota [40,41]. For these reasons, a novel depolymerase enzyme, encoded by Klebsiella phage KP36 from the Siphoviridae family, has been identified and characterized in this study to evaluate its effectiveness against encapsulated bacteria in vitro and in vivo. As other recombinant enzymes that cleave Klebsiella CPS reported so far, were encoded by Podoviridae and Myoviridae phages [8,20,36,38,42], depoKP36 constitutes the first recombinant depolymerase obtained from siphovirus specific against Klebsiella.

NCBI BLAST results revealed that depoKP36 shares about $67-88 \%$ amino-acid identities in the N-terminal region with other putative tail fiber proteins from Klebsiella and Enterobacter phages, belonging to the same family of Siphoviridae and more specifically the "KP36likevirus" genus [22,43]. Such high homology within morphologically similar phages may indicate the presence in this part 
of a domain anchoring the tail fiber to the phage particle. In turn, the exhibition of a C-terminal sequence similarity to the gp57 of Klebsiella phage KP34 from Podoviridae, and the identification of common host spectrum for both phages $[21,44]$ suggests that it is the region responsible for recognizing polysaccharides and binding to the host cell receptor. Also, a pectate lyase domain fragment, found in the sequence alignment, indicates the involvement of depoKP36 in the modification or cleavage of glycoside bonds in the capsular polysaccharide. Previously, this domain has been reported in other phage tail spike proteins targeting and degrading CPS, like K5 lyase of coliphage K5A [45] and Tsp2 of phage $\Phi S H 19$ [46].

Our study proved that depoKP36 is able to digest the capsule from the surface of all isolates with a wzi sequence corresponding to the K63 reference strain. Also, the zymography confirmed that this enzyme efficiently degrades purified EPS from Klebsiella serotype 63. Notably, this polysaccharide

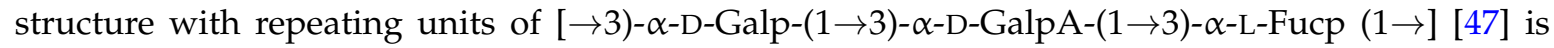
identical to that of E. coli serotype K42 capsular polysaccharide [48], a finding which could potentially extend the spectrum of bacteria susceptible to this protein. Furthermore, modifications of depolymerase could further expand its bacterial spectrum [49]. Indeed, it has been shown that even a single amino acid substitution in the active site of phage HK620 tailspike protein results in an increase of binding affinity of up to three orders of magnitude [50] and that, upon mutations, the enzyme can gain the ability to recognize other bacterial surface receptors [51].

Together with the evaluation of the ability of depoKP36 to degrade capsular polysaccharides in vitro, we investigated its effect in vivo using the G. mellonella model. The innate immune response of insects in many aspects reflects the defensive mechanisms against Klebsiella-triggered pneumonia in animals [34]. In our study, the results obtained on the wax moth larvae model confirm the idea of utilization of these phage-encode proteins as anti-virulent agents. The increased larval survival rates following the application of the enzyme or bacteria treated with it prior to inoculation suggests the decrease in bacterial virulence as the consequence of the loss of capsule layer as the major Klebsiella pathogenicity factor.

Given the improved gentamicin efficacy against K. pneumoniae serotype K2 after using the bacterial depolymerase [40], we further evaluated the activity of depoKP36 in combination with four classes of antibiotics. Unlike the in vivo studies involving the bacterial enzyme [40], our in vitro experiments have not revealed the ability of phage-derived depolymerase to potentiate the efficacy of aminoglycoside antibiotic against K. pneumoniae. Also, the efficacy of ciprofloxacin (fluorochinolones), oksytetracycline (tetracyclines), and chloramphenicol did not change after administration of depoKP36. Nevertheless, besides no improvement of antibiotic activity it is worth mentioning that depolymerase treatment does not disturb drug action. Thus, reducing other virulence factors responsible for the susceptibility to immune response, the final result of depolymerase application may lead to the improvement of the drug/enzyme combined therapy.

Our results showed that depoKP36 displays moderate acidic-stability with the optimum $\mathrm{pH}$ in the range from 4.0 to 7.0, similar to the depolymerase from Klebsiella phage P13 [38]. This $\mathrm{pH}$-dependence of enzyme activity agrees well with the ability of $K$. pneumoniae to infect the urinary tracts, as the $\mathrm{pH}$ of urine ranges from 6.5 to 7.0. From this perspective, such enzymes could be interesting candidates for anti-virulence agents in a hurdle approach for catheter preservation, in addition to other antimicrobial additives. On the contrary, the enzymes from phages specific to K. pneumoniae 390 and B5055 were found to be stable in a $\mathrm{pH}$ range shifted toward more alkaline conditions, from 6.0 to 9.0 or 10.0, respectively $[14,36]$. The activity of depoKP36 was optimal in the range from $20^{\circ} \mathrm{C}$ to $37^{\circ} \mathrm{C}$, what ensures the best efficacy during the therapy, as well as anti-virulent/anti-biofilm preservation agent when applied as catheter additive. The trimeric structure of depoKP36, as reported for other tailspike proteins, including those from phages: P22 [52], Sf6 [53], HK620 [54], phi 29 [55], Det7 [56], and 9NA [57], provides a high stability at different $\mathrm{pH}$ and temperature conditions, but most importantly it increases the avidity of protein-carbohydrate interactions [49]. Unlike most of the described viral fibers, the depoKP36 remains susceptible to SDS-induced denaturation and proteolytic cleavage [33,58]. 
In proteins with a high content of $\beta$-structure, denaturation in the presence of SDS increases the amount of $\alpha$-helix structure [59]. This favors the formation of a "bead-on-a-string" structure, in which the SDS micelles bind to proteins, stabilizing it in this way [60]. This also suggests that SDS-conformational changes might facilitate access of the active site of the enzyme to the substrate.

In conclusion, the identification of a novel depolymerase and the characterization of its catalytic and structural features add insights to the understanding of the mode of action of phage-derived enzymes able to digest bacterial polysaccharides. Altogether, our findings demonstrate that depoKP36 is the enzyme responsible for the ability of KP36 phage to degrade the bacterial capsule, making bacteria less pathogenic and more easy to eradicate by immune response mechanisms. What is more, the bacterial capsule serves as the effective adherence element conditioning the formation of biofilm structure on living and artificial surfaces. Therefore, our results provide grounds to use depoKP36 as a phage-based anti-biofilm tool. Indeed, the observed efficacy, stability, and specificity of depoKP36 makes it suitable for various purposes, including the monitoring of biofilm formation and bacterial detection, coating of medical tools and devices, and glycans analyses.

Acknowledgments: This study were supported by research a grant DEC-2015/19/N/NZ1/00014 of the National Science Centre, Poland and a Polish-Italian Joint Research Project No. AMMCNT-CNR n. 0015976. This article does not contain any studies with human participants or animals performed by any of the authors.

Author Contributions: M.S.G., Ł.A., M.B., S.F., and R.M. carried out the experiments needed to produce protein and characterize its structural features in solution. S.C. determined the capsular type of Klebsiella isolates. M.S.G. and Ł.A. estimated the enzyme activity in vitro. M.S.G performed the studies evaluating the enzyme activity in vivo on G. mellonella model, conducted statistical analyses, and wrote the manuscript. M.S.G., Z.D.K., and B.R. conceived and designed the studies, interpreted the data, and revised the manuscript. L.R. provided expert advice regarding bioinformatics analyses and helped to finalize the manuscript. All authors read and approved the final manuscript.

Conflicts of Interest: The authors declare no conflict of interest.

\section{References}

1. Podschun, R.; Ullmann, U. Klebsiella spp. as nosocomial pathogens: Epidemiology, taxonomy, typing methods, and pathogenicity factors. Clin. Microbiol. Rev. 1998, 11, 589-603. [PubMed]

2. Keynan, Y.; Rubinstein, E. The changing face of Klebsiella pneumoniae infections in the community. Int. J. Antimicrob. Agents 2007, 30, 385-389. [CrossRef] [PubMed]

3. Coque, T.M.; Baquero, F.; Cantón, R. Increasing prevalence of ESBL-producing Enterobacteriaceae in Europe. Euro Surveill. 2008, 13, 5437-5453.

4. Munoz-Price, L.S.; Poirel, L.; Bonomo, R.A.; Schwaber, M.J.; Daikos, G.L.; Cormican, M.; Cornaglia, G.; Garau, J.; Gniadkowski, M.; Hayden, M.K.; et al. Clinical epidemiology of the global expansion of Klebsiella pneumoniae carbapenemases. Lancet Infect. Dis. 2013, 13, 785-796. [CrossRef]

5. Robilotti, E.; Deresinski, S. Carbapenemase-producing Klebsiella pneumoniae. F1000Prime Rep. $2014,6,80$. [CrossRef] [PubMed]

6. Pan, Y.J.; Fang, H.C.; Yang, H.C.; Lin, T.L.; Hsieh, P.F.; Tsai, F.C.; Keynan, Y.; Wang, J.T. Capsular polysaccharide synthesis regions in Klebsiella pneumoniae serotype K57 and a new capsular serotype. J. Clin. Microbiol. 2008, 46, 2231-2240. [CrossRef] [PubMed]

7. Pan, Y.J.; Lin, T.L.; Chen, Y.H.; Hsu, C.R.; Hsieh, P.F.; Wu, M.C.; Wang, J.T. Capsular types of Klebsiella pneumoniae revisited by wzc sequencing. PLoS ONE 2013, 8, e80670. [CrossRef] [PubMed]

8. Hsu, C.R.; Lin, T.L.; Pan, Y.J.; Hsieh, P.F.; Wang, J.T. Isolation of a bacteriophage specific for a new capsular type of Klebsiella pneumoniae and characterization of its polysaccharide depolymerase. PLoS ONE 2013, 8, e70092. [CrossRef] [PubMed]

9. Li, B.; Zhao, Y.; Liu, C.; Chen, Z.; Zhou, D. Molecular pathogenesis of Klebsiella pneumoniae. Future Microbiol. 2014, 9, 1071-1081. [CrossRef] [PubMed]

10. Stewart, P.S. Theoretical aspects of antibiotic diffusion into microbial biofilms. Antimicrob. Agents Chemother. 1996, 40, 2517-2522. [PubMed]

11. Samson, J.E.; Magadán, A.H.; Sabri, M.; Moineau, S. Revenge of the phages: Defeating bacterial defences. Nat. Rev. Microbiol. 2013, 11, 675-687. [CrossRef] [PubMed] 
12. Adams, M.H.; Park, B.H. An enzyme produced by a phage host-cell system. II. The properties of the polysaccharide depolymerase. Virology 1956, 2, 719-736. [CrossRef]

13. Drulis-Kawa, Z.; Majkowska-Skrobek, G.; Maciejewska, B. Bacteriophages and phage-derived proteins-application approaches. Curr. Med. Chem. 2015, 22, 1757-1773. [CrossRef] [PubMed]

14. Bessler, W.; Freund-Mölbert, E.; Knüfermann, H.; Rudolph, C.; Thurow, H.; Stirm, S. A bacteriophage-induced depolymerase active on Klebsiella K11 capsular polysaccharide. Virology 1973, 56, 134-151. [CrossRef]

15. Niemann, H.; Kwiatkowski, B.; Westphal, U.; Stirm, S. Klebsiella serotypes 25 capsular polysaccharide: Primary structure and depolymerization by a bacteriophage-borne glycanase. J. Bacteriol. 1977, 130, 366-374. [PubMed]

16. Rieger-Hug, D.; Stirm, S. Comparative study of host capsule depolymerase associated with Klebsiella bacteriophages. Virology 1981, 113, 363-378. [CrossRef]

17. Lin, T.L.; Hsieh, P.F.; Huang, Y.T.; Lee, W.C.; Tsai, Y.T.; Su, P.A.; Pan, Y.J.; Hsu, C.R.; Wu, M.C.; Wang, J.T. Isolation of a bacteriophage and its depolymerase specific for $\mathrm{K} 1$ capsule of Klebsiella pneumoniae: Implication in typing and treatment. J. Infect. Dis. 2014, 210, 1734-1744. [CrossRef] [PubMed]

18. Dutton, G.G.; DiFabio, J.L.; Leek, D.M.; Merrifield, E.H.; Nunn, J.R.; Stephen, A.M. Preparation of oligosaccharides by the action of bacteriophage-borne enzymes on Klebsiella capsular polysaccharides. Carbohydr. Res. 1981, 97, 127-138. [CrossRef]

19. Mou, H.; Wang, J.; Jiang, X.; Liu, Z. Preparation and properties bacteriophage-borne enzyme degrading bacterial exopolysaccharide. High Technol. Lett. 2008, 14, 210-215.

20. Pan, Y.J.; Lin, T.L.; Lin, Y.T.; Su, P.A.; Chen, C.T.; Hsieh, P.F.; Hsu, C.R.; Chen, C.C.; Hsieh, Y.C.; Wang, J.T. Identification of capsular types in carbapenem-resistant Klebsiella pneumoniae strains by wzc sequencing and implications for capsule depolymerase treatment. Antimicrob. Agents Chemother. 2015, 59, 1038-1047. [CrossRef] [PubMed]

21. Kęsik-Szeloch, A.; Drulis-Kawa, Z.; Weber-Dąbrowska, B.; Kassner, J.; Majkowska-Skrobek, G.; Augustyniak, D.; Lusiak-Szelachowska, M.; Zaczek, M.; Górski, A.; Kropinski, A.M. Characterising the biology of novel lytic bacteriophages infecting multidrug resistant Klebsiella pneumoniae. Virol. J. 2013, 10, 100. [CrossRef] [PubMed]

22. Niu, Y.D.; McAllister, T.A.; Nash, J.H.; Kropinski, A.M.; Stanford, K. Four E. coli O157:H7 phages: A new bacteriophage genus and taxonomic classification of T1-like phages. PLoS ONE 2014, 10, e0142287. [CrossRef] [PubMed]

23. Brisse, S.; Passet, V.; Björk Haugaard, A.; Babosan, A.; Kassis-Chikhani, N.; Struve, C.; Decrée, D. Wzi gene sequencing, a rapid method for determination of capsular type for Klebsiella strains. J. Clin. Microbiol. 2013, 51, 4073-4078. [CrossRef] [PubMed]

24. Laemmli, U.K. Cleavage of structural proteins during the assembly of the head of bacteriophage T4. Nature (Lond.) 1970, 227, 680-685. [CrossRef]

25. Gasteiger, E.; Hoogland, C.; Gattiker, A.; Duvaud, S.; Wilkins, M.R.; Appel, R.D.; Bairoch, A. Protein Identification and Analysis Tools on the ExPASy Server. In The Proteomics Protocols Handbook; Walker, J.M., Ed.; Humana Press: Clifton, NJ, USA, 2005; pp. 571-607.

26. Bales, P.M.; Renke, E.M.; May, S.L.; Shen, Y.; Nelson, D.C. Purification and characterization of biofilm-associated EPS exopolysaccharides from ESKAPE organisms and other pathogens. PLoS ONE 2013, 8, e67950. [CrossRef] [PubMed]

27. Bellemann, P.; Bereswill, S.; Berger, S.; Geider, K. Visualization of capsule formation by Erwinia amylovora and assays to determine amylovoran synthesis. Int. J. Biol. Macromol. 1994, 16, 290-296. [CrossRef]

28. CLSI. Methods for Dilution Antimicrobial Susceptibility Tests for Bacteria That Grow Aerobically, Approved Standard-Ninth Edition; CLSI document M07-A9; Clinical and Laboratory Standards Institute: Wayne, PA, USA, 2012.

29. Altschul, S.F.; Gish, W.; Miller, W.; Myers, E.W.; Lipman, D.J. Basic local alignment search tool. J. Mol. Biol. 1990, 215, 403-410. [CrossRef]

30. Söding, J.; Biegert, A.; Lupas, A.N. The HHpred interactive server for protein homology detection and structure prediction. Nucleic Acids Res. 2005, 33, W244-W248. [CrossRef] [PubMed]

31. Buchan, D.W.A.; Minneci, F.; Nugent, T.C.O.; Bryson, K.; Jones, D.T. Scalable web services for the PSIPRED Protein Analysis Workbench. Nucleic Acids Res. 2013, 41, W340-W348. [CrossRef] [PubMed] 
32. Jenkins, J.; Mayans, O.; Pickersgill, R. Structure and evolution of parallel beta-helix proteins. J. Struct. Biol. 1998, 122, 236-246. [CrossRef] [PubMed]

33. Mitraki, A.; Miller, S.; van Raaij, M.J. Review: Conformation and folding of novel beta-structural elements in viral fiber proteins: The triple beta-spiral and triple beta-helix. J. Struct. Biol. 2002, 137, 236-247. [CrossRef] [PubMed]

34. Insua, J.L.; Llobet, E.; Moranta, D.; Pérez-Gutiérrez, C.; Tomás, A.; Garmendia, J.; Bengoechea, J.A. Modeling Klebsiella pneumoniae pathogenesis by infection of the wax moth Galleria mellonella. Infect. Immun. 2013, 81, 3552-3565. [CrossRef] [PubMed]

35. Verma, V.; Harjai, K.; Chhibber, S. Structural changes induced by a lytic bacteriophage make ciprofloxacin effective against older biofilm of Klebsiella pneumoniae. Biofouling 2010, 26, 729-737. [CrossRef] [PubMed]

36. Kassa, T.; Chhibber, S. Thermal treatment of the bacteriophage lysate of Klebsiella pneumoniae B5055 as a step for the purification of capsular depolymerase enzyme. J. Virol. Methods 2012, 179, 135-141. [CrossRef] [PubMed]

37. Chhibber, S.; Nag, D.; Bansal, S. Inhibiting biofilm formation by Klebsiella pneumoniae B5055 using an iron antagonizing molecule and a bacteriophage. BMC Microbiol. 2013, 13, 174. [CrossRef] [PubMed]

38. Liu, Y.; Li, G.; Mo, Z.; Chai, Z.; Shang, A.; Mou, H. Properties of Klebsiella phage P13 and associated exopolysaccharide depolymerase. J. Ocean Univ. Chin. 2014, 13, 163-168. [CrossRef]

39. Mushtaq, N.; Redpath, M.B.; Luzio, J.P.; Taylor, P.W. Treatment of experimental E. coli infection with recombinant bacteriophage-derived capsule depolymerase. J. Antimicrob. Chemother. 2005, 56, 160-165. [CrossRef] [PubMed]

40. Bansal, S.; Harjai, K.; Chhibber, S. Depolymerase improves gentamicin efficacy during Klebsiella pneumoniae induced murine infection. BMC Infect. Dis. 2014, 14, 456. [CrossRef] [PubMed]

41. Mushtaq, N.; Redpath, M.B.; Luzio, J.P.; Taylor, P.W. Prevention and cure of systemic E. coli K1 infection by modification of the bacterial phenotype. Antimicrob. Agents Chemother. 2004, 48, 1503-1508. [CrossRef] [PubMed]

42. Shang, A.; Liu, Y.; Wang, J.; Mo, Z.; Li, G.; Mou, H. Complete nucleotide sequence of Klebsiella phage P13 and prediction of an EPS depolymerase gene. Virus Genes 2015, 50, 118-128. [CrossRef] [PubMed]

43. Hoyles, L.; Murphy, J.; Neve, H.; Heller, K.J.; Turton, J.F.; Mahony, J.; Sanderson, J.D.; Hudspith, B.; Gibson, G.R.; McCartney, A.L.; et al. Klebsiella pneumoniae subsp. pneumoniae-bacteriophage combination from the caecal effluent of a healthy woman. Peer J. 2015, 3, e1061. [CrossRef] [PubMed]

44. Drulis-Kawa, Z.; Mackiewicz, P.; Kęsik-Szeloch, A.; Maciaszczyk-Dziubinska, E.; Weber-Dąbrowska, B.; Dorotkiewicz-Jach, A.; Augustyniak, D.; Majkowska-Skrobek, G.; Bocer, T.; Empel, J.; et al. Isolation and characterization of KP34-a novel $\phi K M V-l i k e$ bacteriophage for Klebsiella pneumoniae. Appl. Microbiol. Biotechnol. 2011, 90, 1333-1345. [CrossRef] [PubMed]

45. Thompson, J.E.; Pourhossein, M.; Waterhouse, A.; Hudson, T.; Goldrick, M.; Derrick, J.P.; Roberts, I.S. The K5 lyase KflA combines a viral tail spike structure with a bacterial polysaccharide lyase mechanism. J. Biol. Chem. 2010, 285, 23963-23969. [CrossRef] [PubMed]

46. Hooton, S.P.; Timms, A.R.; Rowsell, J.; Wilson, R.; Connerton, I.F. Salmonella typhimurium-specific bacteriophage $\Phi S H 19$ and the origins of species specificity in the Vi01-like phage family. Virol. J. 2010, 8, 498. [CrossRef] [PubMed]

47. Joseleau, J.P.; Marais, M.F. Structure of the capsular polysaccharide of Klebsiella K-type 63. Carbohydr. Res. 1979, 77, 183-190. [CrossRef]

48. Niemann, H.; Chakraborty, A.K.; Friebolin, H.; Stirm, S. Primary structure of the E. coli serotype K42 capsular polysaccharide and its serological identity with the Klebsiella K63 polysaccharide. J. Bacteriol. 1978, 133, 390-391. [PubMed]

49. Simpson, D.J.; Sacher, J.C.; Szymanski, C.M. Exploring the interactions between bacteriophage-encoded glycan binding proteins and carbohydrates. Curr. Opin. Struct. Biol. 2015, 34, 69-77. [CrossRef] [PubMed]

50. Broeker, N.K.; Gohlke, U.; Muller, J.J.; Uetrecht, C.; Heinemann, U.; Seckler, R.; Barbirz, S. Single amino acid exchange in bacteriophage HK620 tailspike protein results in thousand-fold increase of its oligosaccharide affinity. Glycobiology 2013, 23, 59-68. [CrossRef] [PubMed]

51. Drexler, K.; Dannull, J.; Hindennach, I.; Mutschler, B.; Henning, U. Single mutations in a gene for a tail fiber component of an $E$. coli phage can cause an extension from a protein to a carbohydrate as a receptor. J. Mol. Biol. 1991, 219, 655-663. [CrossRef] 
52. Steinbacher, S.; Baxa, U.; Miller, S.; Weintraub, A.; Seckler, R.; Huber, R. Crystal structure of phage P22 tailspike protein complexed with Salmonella sp. O-antigen receptors. Proc. Natl. Acad. Sci. USA 1996, 93, 10584-10588. [CrossRef] [PubMed]

53. Muller, J.J.; Barbirz, S.; Heinle, K.; Freiberg, A.; Seckler, R.; Heinemann, U. An intersubunit active site between supercoiled parallel beta helices in the trimeric tailspike endorhamnosidase of Shigella flexneri phage Sf6. Structure 2008, 16, 766-775. [CrossRef] [PubMed]

54. Barbirz, S.; Muller, J.J.; Uetrecht, C.; Clark, A.J.; Heinemann, U.; Seckler, R. Crystal structure of E. coli phage HK620 tailspike: Podoviral tailspike endoglycosidase modules are evolutionarily related. Mol. Microbiol. 2008, 69, 303-316. [CrossRef] [PubMed]

55. Xiang, Y.; Leiman, P.G.; Li, L.; Grimes, S.; Anderson, D.L.; Rossmann, M.G. Crystallographic insights into the autocatalytic assembly mechanism of a bacteriophage tail spike. Mol. Cell 2009, 34, 375-386. [CrossRef] [PubMed]

56. Walter, M.; Fiedler, C.; Grassl, R.; Biebl, M.; Rachel, R.; Hermo-Parrado, X.L.; Llamas-Saiz, A.L.; Seckler, R.; Miller, S.; van Raaij, M.J. Structure of the receptor-binding protein of bacteriophage det7: A podoviral tail spike in a myovirus. J. Virol. 2008, 82, 2265-2273. [CrossRef] [PubMed]

57. Andres, D.; Roske, Y.; Doering, C.; Heinemann, U.; Seckler, R.; Barbirz, S. Tail morphology controls DNA release in two Salmonella phages with one lipopolysaccharide receptor recognition system. Mol. Microbiol. 2012, 83, 1244-1253. [CrossRef] [PubMed]

58. Manning, M.; Colón, W. Structural basis of protein kinetic stability: Resistance to sodium dodecyl sulfate suggests a central role for rigidity and a bias toward beta-sheet structure. Biochemistry 2004, 43, 11248-11254. [CrossRef] [PubMed]

59. Takeda, K.; Sasaoka, H.; Sasa, K.; Hirai, H.; Hachiya, K.; Moriyama, Y. Size and mobility of sodium dodecyl-sulfate bovine serum-albumin complex as studied by dynamic light-scattering and electrophoretic light-scattering. J. Coll. Int. Sci. 1992, 154, 385-392. [CrossRef]

60. Ibel, K.; May, R.P.; Kirschner, K.; Szadkowski, H.; Mascher, E.; Lundahl, P. Protein-decorated micelle structure of sodium-dodecyl-sulfate-protein complexes as determined by neutron scattering. Eur. J. Biochem. 1990, 190, 311-318. [CrossRef] [PubMed] 